\title{
Optimization of worm-bed leachate for culturing of tomato (Lycopersicon esculentum Mill) inoculated with Glomus fasciculatum and Pseudomonas fluorescens
}

\author{
María Ángela Oliva-Llaven \\ Facultad de Medicina Veterinaria y Zootecnia \\ Universidad Autónoma de Chiapas \\ Chiapas, México \\ Ludwi Rodríguez-Hernández \\ Instituto Tecnológico de Tuxtla Gutiérrez \\ Chiapas, México \\ Paula Mendoza-Nazar \\ Facultad de Medicina Veterinaria y Zootecnia \\ Universidad Autónoma de Chiapas \\ Chiapas, México \\ Benigno Ruiz-Sesma \\ Facultad de Medicina Veterinaria y Zootecnia \\ Universidad Autónoma de Chiapas \\ Chiapas, México \\ José David Álvarez-Solís* \\ Departamento de Agroecología \\ Colegio de la Frontera Sur \\ Chiapas, México \\ E-mail: dalvarez@ecosur.mx

\section{Luc Dendooven} \\ Laboratorio de Ecología de Suelos \\ Departamento de Biotecnología y Bioingeniería \\ Centro de Investigación y de Estudios Avanzados \\ Instituto Politécnico Nacional \\ México

\section{Federico A. Gutiérrez-Miceli \\ División de Posgrado e Investigación \\ Instituto Tecnologico de Tuxtla Gutiérrez Chiapas, México}

Keywords: Glomus fasciculatum, organic cultivation of tomato, $\mathrm{pH}$ in tomato fruit, soluble solids.

Abbreviations: FAWBL: frequency of application of worm-bed leachate RSM: response surface methodologies

WBL: worm-bed leachate
A response surface technique was used to analyze the effect of Glomus fasciculatum, Pseudomonas fluorescens and worm-bed leachate (WBL) on growth, yield and characteristics of tomato (Lycopersicon esculentum Mill). The treatments combined inoculation with or without $P$. fluorescensor $G$. fasciculatum and the application of WBL at $20 \%(\mathrm{v} / \mathrm{v})$ each day or every three days. Plant height, number of leaves and yield of tomato fruits was not affected by the factors studied. However, plants with foliar application of WBL each day developed wider stems than those with an application every three days. The $\mathrm{pH}$ of the fruits was lower when WBL was applied every three days compared to a daily application. The soluble solids content of the fruits was higher when WBL was applied daily compared to those sprayed every three days. Plant development was not affected by addition of $P$. fluorescens, G. fasciculatum or WBL, but WBL changed fruit characteristics.

*Corresponding author 
Tomato (Lycopersicon esculentum Mill.) originates from the Andean region of South America. It was probably the Aztecs, living in modern day México, who domesticated the crop over 1,500 years ago. This crop is one of the most popular and widely grown vegetables in the world. Leader tomato producing countries include China, USA, Turkey, Russia, Italy, India, Spain and México. In 1999, the global tomato production was $9.4 \times 10^{9} \mathrm{~kg}$ cultivated on 5.5 million ha, but production and land cultivated with them is still increasing. Fresh tomatoes are key ingredients in cooking all around the world and processed tomatoes are used to make soup, juice, ketchup, puree and other products. The vast majority of tomatoes are still produced with conventional production systems, i.e., the use of large amounts of fertilizer and pesticides (Hasna et al. 2007). The importance of tomato in many diets and the large amounts of pesticide used to cultivation raises concern about the health and safety of workers, small scale farmers and consumers (Cavagnaro et al. 2006). In today's health conscious society, there is increasing demand for organic agricultural products. Therefore, growers increasingly prefer to cultivate tomatoes 'organically' for a variety of reasons. One of the advantages of organic cultivated crops is that they often give a $10-30 \%$ premium on the market (Cavagnaro et al. 2006). Other benefits are the possibility of reduced production costs, improved farm safety, reduced environmental impact and sustainable agro-ecosystems (Tu et al. 2006). Organic agriculture is an alternative to conventional production system, and it can contribute to socio-economic and ecologically sustainable development, especially in poorer countries. The use of vermicompost in the organic production of tomato in the greenhouse might decrease costs, increase yields, improve the fruit composition and reduce negative effects on the environment (Atiyeh et al. 2000). For instance, improvement in phytonutrients in tomatoes can be achieved by cultivar selection, environmental factors and agronomic practices (Dorais et al. 2008).

In the vermicomposting process, beds filled with composted waste, earthworms and bedding material are fitted with a drainage and collection system. Leachate derived from vermicomposting often called 'worm tea' or 'worm-bed leachate' (WBL) can be used as a liquid fertiliser as it contains large amounts of plant nutrients (Warburton and Pillai-McGarry, 2002). Apart from its large nutrient content, WBL might contribute to plant growth as it contains humic acids (Arancon et al. 2005). Humic acids regulate processes involved in plant development, such as macro and micro nutrient uptake (Atiyeh et al. 2002).

Berta et al. (2005) reported that Glomus mosseae in combination with Pseudomonas fluorescens suppresses the soilborne disease Rhizoctonia solani root-rot in tomato, this result indicates that AM fungi can be used as biocontrol agents of tomato. Mycorrhizal tomato plants had significantly less Alternaria solani symptoms than nonmycorrhizal plants (Fritz et al. 2006). Poulton et al. (2002) reported that Glomus etunicatum, a mycorrhizal fungus, significantly increased above-ground dry mass, root length, phosphorus (P) content and yield of tomato under $\mathrm{P}$ limited conditions. Mena-Violante et al. (2006) evaluated the effect of $G$. fasciculatum on chile ancho (Capsicum annum L.) and found that fruit fresh weight was $25 \%$ greater in comparison to non-inoculated plants. In a greenhouse experiment, the weight of maize plants cultivated in peat moss amended with vermicompost increased when supplemented with $G$. fasciculatum (Gutiérrez-Miceli et al. 2008). However, host plant responsiveness to mycorrhizal colonization is highly variable (Poulton et al. 2002). The effect of these fungi on growth is not only different between plant species, but also between genotypes of the same species.

Colonization by Pseudomonas fluorescens affects root development in a complex way, causing an early stimulation of the primary root growth in tomato plants (Gamalero et al. 2005). P. fluorescens also acts as elicitor of plant defence reactions and can therefore be used to control pests in organic farmed crops (Diby and Sarma, 2006).

Worm-bed leachate is increasingly being used in Mexico, but little is known how it could be used in 'organic' culturing of tomato. We investigated how worm-bed leachate, added with $P$. fluorescens and G. fasciculatum affected growth, yield and fruits characteristics, i.e., soluble solids and $\mathrm{pH}$, of tomato plantscultivated in a commercial nursery.

\section{MATERIALS AND METHODS}

\section{Worm-bed leachate}

Eight beds (1.5 m by $6.6 \mathrm{~m}$ and $1 \mathrm{~m}$ deep) were used to obtain worm-bed leachate. Each bed was covered with a plastic sheet to protect the vermicompost against sun and rain. A total bed area of $79 \mathrm{~m}^{2}$ was available. Cow manure was composted thermophilically for two months while mechanically being turned over every 15 days. The composted cow manure, adjusted to $80 \%$ moisture content, was placed in the beds to a depth of $0.5 \mathrm{~m}$ and earthworms (Eisenia fetida) were added at a rate of $25 \mathrm{~g}$ earthworms $/ \mathrm{kg}$ cow manure or $2.5 \mathrm{~kg}$ earthworms $\mathrm{m}^{-2}$ bed. The mixture was left to vermicompost for two months.

Each bed contained a leachate drainage and collection system. Leachate from each bed was collected in a separate $200 \mathrm{l}$ tank, pumped into a central collection $1500 \mathrm{l}$ tank and characterized.

\section{Characteristics of the worm-bed leachate}

The germination index for tomato seed (L. lycopersicum Mill) cv Sunn 7,705 was determined by placing a filter paper in a Petri dish and submerging it with worm-bed leachate. Seeds of tomato were placed on the filter paper and the Petri dish was covered with a larger filter paper. The number of seeds germinating was measured after 

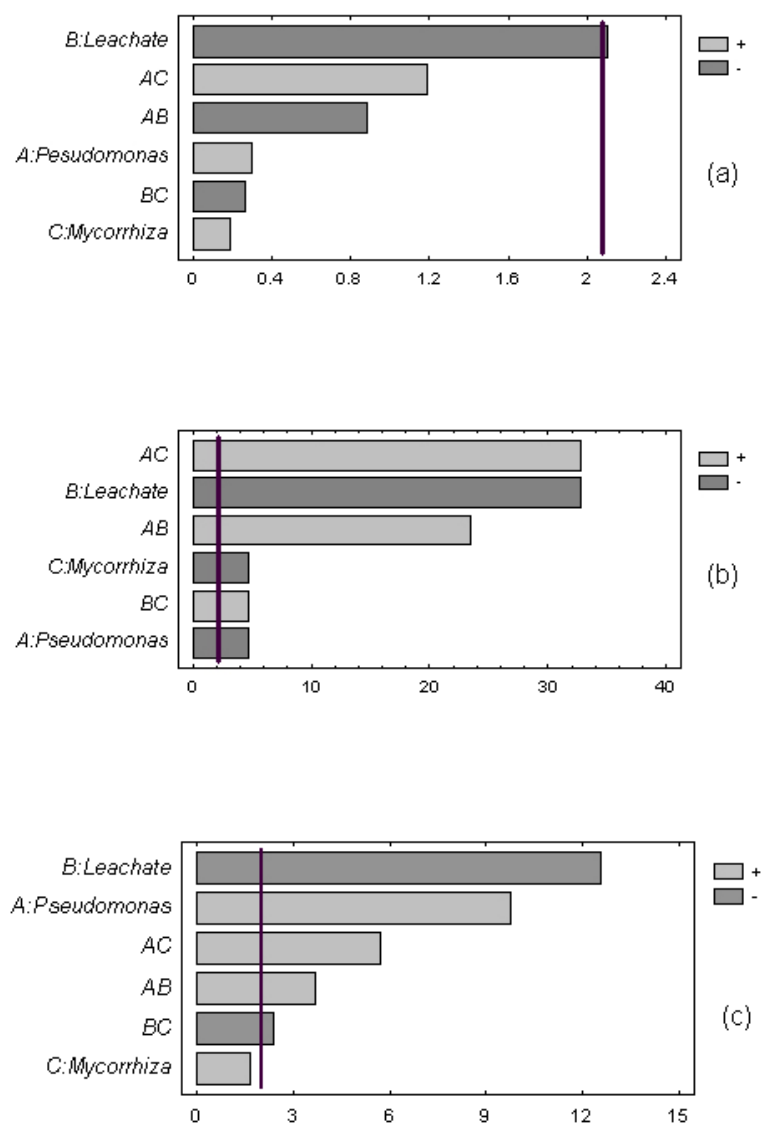

Figure 1. Standardized Pareto chart to investigate the effect of Pseudomonas fluorescens, Glomus fasciculatum and frequency of worm bed leachate application on stem diameter (cm, a), $\mathrm{pH}$ of the fruits (units, b) and soluble solids of the fruits $(\mathrm{g} / \mathrm{kg}, \mathrm{c})$ of tomato plants.

incubating the covered Petri dishes in the dark at $28^{\circ} \mathrm{C}$ for 8 days (Alvarez and Grigera, 2005).

Details of the methods used to characterize the chemical composition of WBL can be found in Contreras-Ramos et al. (2004) and Sánchez-Monedero et al. (1996).

The worm-bed leachate was analyzed for total and faecal coliforms (Escherichia coli), Salmonella sp. and Shigella spp. (USEPA, 1999). Salmonella and Shigella were determined by serial dilution. A sub-sample of $10 \mathrm{ml}$ worm-bed leachate was added to $90 \mathrm{ml} 1 \%$ peptone solution under sterile conditions and $10^{-1}, 10^{-2}$ and $10^{-3}$ dilutions were made with sterile $0.8 \% \mathrm{NaCl}$ solution. A 100 $\mu \mathrm{l}$ aliquot was plated on two selective media SalmonellaShigella agar and sulphite-bismuth agar. The second medium is highly specific for Salmonella. The colonies were identified by form and colour (USEPA, 1999). For the measurement of total and faecal coliforms (E. coli), a 100 $\mu \mathrm{l}$ aliquot of each serial dilution was incubated in lactose broth for at $35^{\circ} \mathrm{C}$ for $24 \mathrm{hrs}$ and total coliforms were counted. The faecal coliforms were differentiated from the rest of the coliforms by incubating a $100 \mu \mathrm{l}$ aliquot of each serial dilution in E. coli medium at $44^{\circ} \mathrm{C}$. Gas production in each assay was considered as positive after $48 \mathrm{hrs}$. Results were confirmed by plating on eosin methylene blue (EMB) agar, incubating for $24 \mathrm{hrs}$, and examining for typical coliform colonies (USEPA, 1999).

The worm-bed leachate (mean of three samples collected every 8 weeks) had $\mathrm{pH} 7.8 \pm 0.1$, electrolytic conductivity $2.6 \pm 0.2 \mathrm{dS} / \mathrm{m}, 128.3 \pm 42.2 \mathrm{mg}$ suspended solids $/ \mathrm{l} ; 46 \pm$ $12 \mathrm{mg} \mathrm{Na}^{+} /$, no detectable $\mathrm{NH}_{4}{ }^{+}, 834 \pm 71 \mathrm{mg} \mathrm{K}^{+} / \mathrm{l}, 59 \pm 9$ $\mathrm{mg} \mathrm{Mg}^{2+} / \mathrm{l}, 84 \pm 13 \mathrm{mg} \mathrm{Ca}^{2+} / 1,130 \pm 2 \mathrm{mg} \mathrm{Cl}^{-} / 1,247 \pm 43$ $\mathrm{mg} \mathrm{NO}{ }^{-} / \mathrm{l}, 168 \pm 11 \mathrm{mg} \mathrm{PO}{ }^{3-} / \mathrm{l}, 47 \pm 13 \mathrm{mg} \mathrm{SO}_{4}{ }^{2-} / \mathrm{l}$. The fulvic acid concentration was $1.5 \%$ and the humic acid $2.4 \%$ of the total $\mathrm{C}$ content of the worm-bed leachate. As such, the humic to fulvic acid ratio was 1.6. The electrolytic conductivity of the vermicomposting leachate was low indicating low concentrations of dissolved salts while it contained large amounts of $\mathrm{K}^{+}, \mathrm{NO}_{3}^{-}$and $\mathrm{PO}_{4}{ }^{3-}$. Considering the above mentioned characteristics, the vermicomposting leachate could easily be used as a fertilizer.

The germination index for tomato was $55 \pm 5 \%$. A germination index $>50 \%$ indicates that the worm-bed leachate is mature (Alvarez and Grigera, 2005). The wormbed leachate was free of pathogens, i.e.coliforms (Escherichia coli), Salmonella sp. and Shigella spp.The reduction of pathogens in the worm-bed leachate could be due at physical and biological factors during vermicomposting ( $\mathrm{Li}$ et al. 2008).

\section{Glomus fasciculatum and Pseudomonas fluorescens}

$G$. fasciculatum and $P$. fluorescens were obtained from the Cinvestav-Irapuato microbial collection (Mexico). Tomato plants were inoculated with or without $P$. fluorescensat $3 \mathrm{x}$ $10^{8} \mathrm{cell} / \mathrm{ml}$ (Gamalero et al. 2005) and G. fasciculatum at 2,250 spores/plant (Mena-Violante et al. 2006).

\section{Cultivation of tomatoes and growth parameters}

Three tomato seeds (L. lycopersicum Mill.) of the Sunn 7,705 cultivar were placed in small PVC containers filled with 50 g Canadian sphagnum peat moss potting material. The Sunn 7,705 cultivar is characterized by continuous growth and the production of flowers at every third internode, but it needs staking and pruning. After sowing, the pots were placed in a greenhouse until the seeds germinated. After germination, 320 tomato plantlets were transplanted to soil with $\mathrm{pH} 8.4$, organic matter content 47 $\mathrm{g} / \mathrm{kg}$, total N content $2.3 \mathrm{~g} / \mathrm{kg}$, P-Olsen $22.2 \mathrm{mg} / \mathrm{kg}$, and a particle size distribution of $640 \mathrm{~g}$ clay $/ \mathrm{kg}, 100 \mathrm{~g}$ sand $/ \mathrm{kg}$ and $260 \mathrm{~g}$ silt/ $/ \mathrm{kg}$ amended with $10 \mathrm{~g}$ vermicompost. Plants were grown under $60 \%$ black knitted shade cloth without temperature control and grouped in plots $7 \mathrm{~m}$ long and 2.1 m wide each containing 10 plants spaced $70 \mathrm{~cm}$ apart. As such 32 groups of ten plants were obtained, i.e. eight 
treatments with four replicates (Table 1). Each group of ten plants was separated $1 \mathrm{~m}$ from each other. Plants were secured to vertical nylon strings hung from horizontal ceiling wires $3 \mathrm{~m}$ above the greenhouse floor. The ten plants were monitored for growth and harvested. All treatments were drip irrigated with tap water ranging from 1 to $2 \mathrm{dm}^{3}$ per plant per day depending of soil water content and crop maturity. Worm-bed leachate was applied by spraying the underside of the leaves until run-off using a single nozzle $18 \mathrm{l}$ backpack sprayer with a $1 \mathrm{~mm}$ spray orifice and an application pressure of between 68.9 and 137 KPa (Hudson Industrial Sprayer \# 65,010) around 6 pm.

The plant height, stem diameter and number of leaves were measured 70 days after transplanting (DAT). At first harvest, the number of fruits and their weight was determined for each plant. Fruits were separated into marketable and non-marketable, i.e. cracked, damaged and infected, and only marketable ones were used to calculate yields (Atiyeh et al. 2000). The results reported here are the mean of ten plants and four replicates for each of the eight treatments. A total of 320 plants were thus monitored and harvested.

\section{Chemical analyses of the tomato fruits}

All marketable tomato fruits were cut into small parts and mixed. Mixing was done manually to homogenize the samples. A $10 \mathrm{~g}$ sub-sample was pressed through cheese cloth to extract the juice, which was analysed for $\mathrm{pH}$ and soluble solids. A $5 \mathrm{ml}$ aliquot of the tomato juice was added to $100 \mathrm{ml}$ distilled water and the $\mathrm{pH}$ was measured using a 130 Conductronic $\mathrm{pH}$ meter (Conductronic S.A. 72,470 Puebla, México) fitted with a glass electrode. Soluble solids of the fruits were determined with a portable refractometer 300,003 (Sper Scientific Ltd., Scottsdale, Arizona, USA) standardized with distilled water.

\section{Statistical analyses}

Growth, fruit characteristics and yield of the tomato plants were subjected to a one-way analysis of variance to test for significant difference between the treatments (SAS Institute, 1989). The Statgraphic Plus Software (1999) was used for the regression analysis of the experimental data obtained. The quality of the fit of the model was expressed by the coefficient of determination $\mathrm{R}^{2}$ and its statistical significance checked by an F-test. The significance of the regression coefficient was tested by a t-test. The level of significance was $P<0.05$. A differential calculation method was then used to predict the optimum.

\section{RESULTS}

\section{Growth and yield parameters}

A factorial experimental design with eight treatments in four blocks with different combinations of $P$. fluorescens, frequency of application of worm-bed leachate (FAWBL) and $G$. fasciculatum was used to obtain optimal conditions
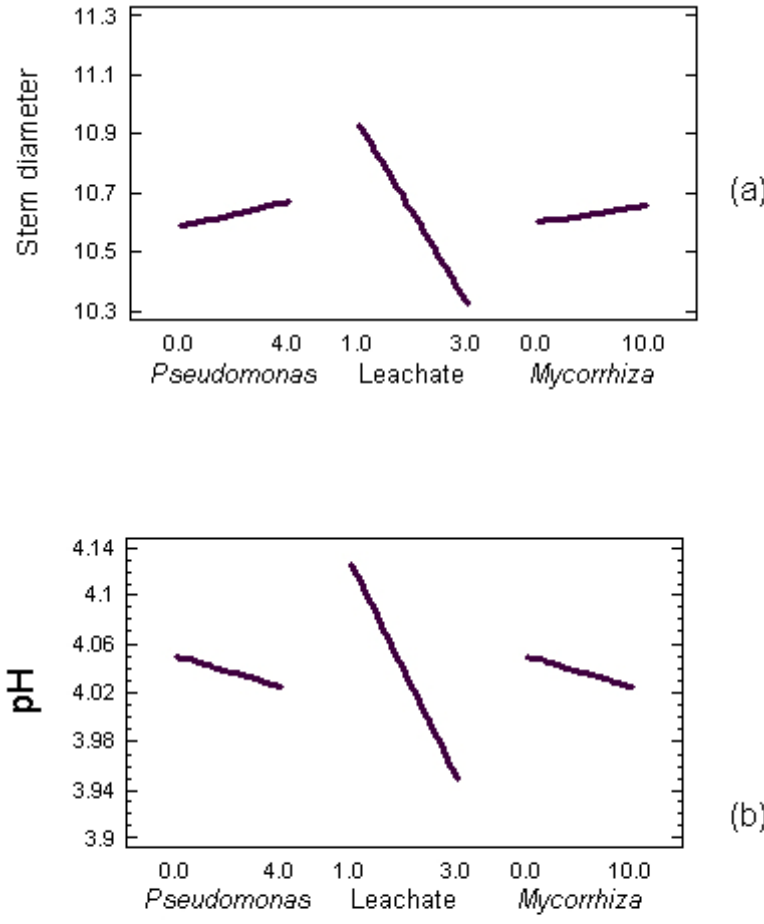

(b)

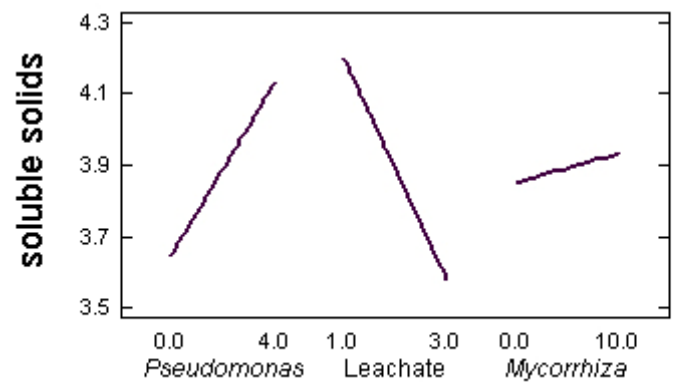

(c)

Figure 2. Main effects of Pseudomonas fluorescens, Glomus fasciculatum and frequency of worm bed leachate application on stem diameter of tomato plants $(\mathrm{cm}, \mathrm{a}), \mathrm{pH}$ (units, b) and soluble solids of the fruits $(\mathrm{g} / \mathrm{kg}, \mathrm{c})$.

for tomato growth and fruit characteristics (Table 1). Plant height ranged from 121 to $134 \mathrm{~cm}$, but was not significantly different between the treatments. Tomato yields and number of leaves per plant ranged from 2.8 to $3.8 \mathrm{~kg}$ from 115 to 123 , respectively but treatments had no significant effect on them. Stem diameter varied from $1.0 \mathrm{~cm}$ to $1.1 \mathrm{~cm}$ and the frequency of leachate application affected the stem diameter significantly $(P<0.05)$ (Figure 1a). Plants with foliar application of WBL each day were significantly broader than those with an application every three days $(P$ $<0.05$ ) (Figure 2a). The equation that fitted the data was:

Stem diameter $=11.0+0.0619 \times \mathrm{A}-0.137 \times \mathrm{FAWBL}-$ $0.0133 \times$ B- $0.0628 \times$ A $\times$ FAWBL $+0.0169 \times$ A x B $0.00763 \times$ FAWBL $\times$ B, 
Table 1. Experimental design to the study the effect of Pseudomonas fluorescens $\left(3 \times 10^{8} \mathrm{cell} /(\mathrm{ml}\right.$ plant $\left.)\right)$, frequency of wormbed leachate application and Glomus fasciculatum (2,250 spores/(g plant)) on plant growth and fruits characteristics of tomato.

\begin{tabular}{|c|c|c|c|c|c|c|c|c|c|}
\hline & & FWBL $^{a}$ & & Height & $S D^{b}$ & & Yield & $\mathrm{pH}$ & SS $^{d}$ \\
\hline Treatment & $\begin{array}{c}P . \\
\text { fluprescens }\end{array}$ & (days) & G. & \multicolumn{2}{|c|}{$(\mathrm{cm})$} & $\operatorname{LN}^{c}$ & (kg/plant) & fruit & (g/kg) \\
\hline 1 & Control & 1 & Control & $131 \mathrm{a}$ & $1.1 \mathrm{a}$ & $118 \mathrm{a}$ & $2.8 \mathrm{a}$ & $4.3 \mathrm{a}$ & $4.0 \mathrm{~b}$ \\
\hline 2 & Control & 1 & Inoculated & $127 \mathrm{a}$ & $1.1 \mathrm{a}$ & $118 \mathrm{a}$ & $3.0 \mathrm{a}$ & $4.1 \mathrm{~b}$ & $4.0 \mathrm{~b}$ \\
\hline 3 & Control & 3 & Control & $132 \mathrm{a}$ & $1.1 \mathrm{a}$ & $116 \mathrm{a}$ & $3.3 \mathrm{a}$ & $4.0 \mathrm{bc}$ & $4.0 \mathrm{~b}$ \\
\hline 4 & Control $^{\mathrm{e}}$ & 3 & Inoculated & $127 \mathrm{a}$ & $1.1 \mathrm{a}$ & $119 \mathrm{a}$ & $3.0 \mathrm{a}$ & $3.9 \mathrm{c}$ & $3.0 \mathrm{c}$ \\
\hline 5 & Inoculated & 1 & Control & $134 \mathrm{a}$ & $1.1 \mathrm{a}$ & $115 \mathrm{a}$ & $3.3 \mathrm{a}$ & $4.0 \mathrm{bc}$ & $4.0 \mathrm{~b}$ \\
\hline 6 & Inoculated & 1 & Inoculated & $131 \mathrm{a}$ & $1.1 \mathrm{a}$ & $123 \mathrm{a}$ & $3.8 \mathrm{a}$ & $4.1 \mathrm{~b}$ & $5.0 \mathrm{a}$ \\
\hline 7 & Inoculated & 3 & Control & $121 \mathrm{a}$ & $1.0 \mathrm{a}$ & $115 \mathrm{a}$ & $3.0 \mathrm{a}$ & $3.9 c$ & $4.0 \mathrm{~b}$ \\
\hline 8 & Inoculated & 3 & Inoculated & $131 \mathrm{a}$ & $1.0 \mathrm{a}$ & $118 \mathrm{a}$ & $3.3 \mathrm{a}$ & $4.1 \mathrm{~b}$ & $4.3 b$ \\
\hline \multicolumn{2}{|c|}{$\operatorname{LSD}^{f}(P<0.05)$} & & & 18 & 0.1 & 11 & 1.2 & 0.1 & 0.3 \\
\hline
\end{tabular}

${ }^{a}$ FWBL: Frequency of worm-bed leachate application; ${ }^{b} \mathrm{SD}$ : Stem diameter; ${ }^{\mathrm{c} L N}$ : Number of leaves; ${ }^{\mathrm{d} S S}$ : Soluble solids in the fruits, ${ }^{\mathrm{e}} \mathrm{Control}$ : Tomato plants that were not inoculated, ${ }^{f}$ LSD: Least significant difference.

$R^{2}=46.5$

With A: P. fluorescens, B: G. fasciculatum.

The broadest plant stems were obtained with $10 \mathrm{~g} G$. fasciculatum/plant and $4 \mathrm{ml} P$. fluorescens applied to soil while spraying the worm-bed leachate every day (Figure 3a). With these values, the predicted maximum stem diameter was $1.13 \mathrm{~cm}$.

\section{$\mathrm{pH}$ and soluble solids of tomato fruits}

The $\mathrm{pH}$ of tomato fruits varied from 3.9 to 4.3 (Table 1) and was significantly affected by FAWBL $(P<0.05)$ (Figure 1b). The $\mathrm{pH}$ was lower when WBL was applied every three days compared to a daily application (Figure 2b). The equation that fitted the data was:

$\mathrm{pH}=3.63-0.059 \times \mathrm{A}+0.222 \times \mathrm{FAWBL}-0.00125 \times \mathrm{B}+$ $0.0141 \times$ A x FAWBL + 0.00406 x A x B -0.00188 x FAWBL $x$ B

$R^{2}=99.2$
Tomato fruits with the lowest $\mathrm{pH}$ were obtained without $G$. fasciculatum and $P$. fluorescens while spraying the tomato plant each day (Figure 3b). The model predicted a minimum $\mathrm{pH}$ of 3.6 .

Soluble solids in tomato fruits varied from 3.0 to $5.0 \mathrm{mg} / \mathrm{kg}$ (Table 1). The FAWBL and interaction between FAWBL and $G$. fasciculatum had a significant effect on soluble solids in tomato fruits $(P<0.05)$ (Figure 1c). The soluble solids content was higher when the WBL was applied daily compared to those sprayed every three days (Figure 2c). The equation that fitted the data was:

Soluble solids $=4.88-0.0281 \times$ A $-0.522 \times$ FAWBL + $0.0175 \times \mathrm{B}+0.0109 \times \mathrm{A} \times \mathrm{FAWBL}+0.00406 \times \mathrm{A} \times \mathrm{B}-$ $0.0169 \times$ FAWBL $x$ B

$R^{2}=93.4$

The response surface plot indicated that higher soluble solids in the tomato fruits were obtained without $G$. fasciculatum and $P$. fluorescens, but spraying the worm-bed leachate each day (Figure 3c). Under these conditions, the model predicted $44.6 \mathrm{mg} / \mathrm{kg}$ soluble solids in tomato fruit. 


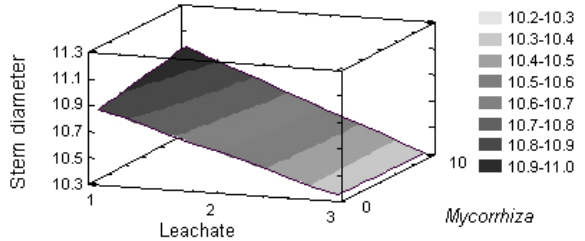

Figure 3. Response surface plots showing the relative effect of Glomus fasciculatum and frequency of worm bed leachate application on stem diameter of tomato plants $(\mathrm{cm}$, a), $\mathrm{pH}$ (units, b) and soluble solids of the fruits $(\mathrm{g} / \mathrm{kg}, \mathrm{c})$.

\section{DISCUSSION}

Response surface methodologies (RSM) have been used to optimize culture conditions in diverse biotechnology processes. It has been used to optimize the medium for lipopeptide iturin production (Mizumoto and Shoda, 2007), to enhance acetoin production (Xiao et al. 2007), and to optimize inactivation of endospores of Bacillus cereus (Huang et al. 2007). RSM includes different statistical techniques related to experimental design, model development, and evaluation of factors, identifying optimum conditions and also to study interactions between variables (Lin et al. 2007; Liu and Wang, 2007). In our work, we used RSM to evaluate how the application rate of vermicompost leachate and the addition of two microorganisms, P. fluorescens and $G$. fasciculatum affected growth, yield, soluble solids and $\mathrm{pH}$ of tomato plants cultivated in a commercial nursery.

It has been reported that foliar application of aqueous vermicompost extracts onto three field-grown tomato varieties had no significant effects on plant growth, biomass and nutrient allocation (Zaller, 2006). In the experiment reported here foliar application of aqueous vermicompost extracts together with $G$. fasciculatum and $P$. fluorescens increased stem diameter. It has been demonstrated that the mycorrhizal fungus, but not the bacterial strains, promoted plant growth, however bacteria induced synergistic effects on plant biomass and the results suggest a key role of the bacteria producing 1aminocyclopropane-1-carboxylate (ACC) deaminase enzyme that modulate plant ethylene levels (Gamalero et al. 2008). Additionally, some fruit characteristics were affected. The $\mathrm{pH}$ of the fruits was lower when WBL was applied every three days compared to a daily application. The soluble solids content of the fruits, however, was higher when WBL was applied daily compared to those sprayed every three days. Zaller (2006) reported that vermicompost spraying consistently increased fruit size as well as $\mathrm{N}$ content, but decreased L-ascorbic acid compared with water sprayed fruits. It can be assumed that microorganisms in the leachate or humic substances in the extracts affected fruit quality. It has been shown that mycorrhizal fungi and the level of soil phosphorus increased fruit and seed development (Poulton et al. 2002). Plants with higher concentrations of $\mathrm{P}$ produce more organic acids so that $\mathrm{pH}$ of the fruits is lower (Poulton et al. 2002). Gutiérrez-Miceli et al. (2007) reported that the addition of vermicompost increased soluble and insoluble solids in tomatoes compared to untreated ones. Azarmi et el. (2008) demonstrated that addition of vermicompost had significant positive effects on growth, yield and elementary content of tomato plants as compared to control. It might be that vermicompost leachate changed the physicochemical, microbial and biological characteristics of the soil thereby improving the nutrient status of the soil or certain substances in the WBL directly affected fruit characteristics (Atiyeh et al. 2000).

\section{CONCLUDING REMARKS}

In conclusion, this study showed that yield, height and number of leaves of the tomato plant were not affected by the factors studied. However, worm-bed leachate added with $P$. fluorescens and G. fasciculatum affected stem diameter, and the soluble solids and $\mathrm{pH}$ of the tomato fruits. Daily applications of worm-bed leachate increased stem diameter, while $\mathrm{pH}$ of the fruits was lower when worm-bed leachate was applied every three days. The soluble solids content of the tomato fruits was higher when the worm bed leachate was applied daily.

\section{REFERENCES}

ALVAREZ, R. and GRIGERA, S. Analysis of soil fertility and management effects on yields of wheat and corn in the rolling pampa of Argentina. Journal of Agronomy and Crop Science, September 2005, vol. 191, no. 5, p. 321-329.

ARANCON, Norman Q.; EDWARDS, Clive A.; BIERMAN, Peter; METZGER, James D. and LUCHT, Chad. Effects of vermicomposts produced from cattle manure, food waste and paper waste on the growth and yield of peppers in the field. Pedobiologia, August 2005, vol. 49, no. 4, p. 297-306. 
ATIYEH, R.M.; ARANCON, N.; EDWARDS, C.A. and METZGER, J.D. Influence of earthworm-processed pig manure on the growth and yield of greenhouse tomatoes. Bioresource Technology, December 2000, vol. 75, no. 3, p. 175-180.

ATIYEH, R.M.; ARANCON, N.Q.; EDWARDS, C.A. and METZGER, J.D. The influence of earthworm-processed pig manure on the growth and productivity of marigolds. Bioresource Technology, January 2002, vol. 81, no. 2, p. 103-108.

AZARMI, Rasool; ZIVEH, Parviz S. and SATARI, Mohammad R. Effect of vermicompost on growth, yield and nutrition status of tomato (Lycopersicum esculentum). Pakistan Journal of Biological Science, July 2008, vol. 11, no. 14, p. 1797-1802.

BERTA, Graziella; SAMPO, Simonetta; GAMALERO, Elisa; MASSA, Nadia and LEMANCEAU, Philippe. Suppression of Rhizoctonia root-rot of tomato by Glomus mossae BEG12 and Pseudomonas fluorescens A6RI is associated with their effect on the pathogen growth and on the root morphogenesis. European Journal of Plant Pathology, March 2005, vol. 111, no. 3, p. 279-288.

CAVAGNARO, T.R.; JACKSON, L.E.; SIX, J.; FERRIS, H.; GOYAL, S.; ASAMI, D. and SCOW, K.M. Arbuscular mycorrhizas, microbial communities, nutrient availability, and soil aggregates in organic tomato production. Plant and Soil, April 2006, vol. 282, no. 1-2, p. 209-225.

CONTRERAS-RAMOS, S.M.; ESCAMILLA-SILVA, E.M. and DENDOOVEN, L. Vermicomposting of biosolids with cow manure and oat straw. Biology and Fertility of Soils, April 2004, vol. 41, no. 3, p. 190-198.

DIBY, P. and SARMA, Y.R. Rhizospheric Pseudomonas fluorescens enhances piperine production in Piper nigrum, a possible means of biochemical defense against Phytophthora capsici. Archives of Phytopathology and Plant Protection, February 2006, vol. 39, no. 1, p. 33-37.

DORAIS, Martine; EHRET, David and PAPADOPOULOS, Athanasios P. Tomato (Solanum lycopersicum) health components: from the seed to the consumer. Phytochemistry Reviews, July 2008, vol. 7, no. 2, p. 231-250.

FRITZ, Maendy; JAKOBSEN, Iver; LYNGKJAER, Michael F.; THORDAL-CHRISTENSEN, Hans and PONS-KÜHNEMANN, Jöns. Arbuscular mycorrhiza reduces susceptibility of tomato to Alternaria solani. Mycorrhiza, September 2006, vol. 16, no. 6, p. 413-419.

GAMALERO, Elisa; LINGUA, Guido; TOMBOLINI, Riccardo; AVIDANO, Lorena; PIVATO, Barbara and BERTA, Graziella. Colonization of tomato root seedling by Pseudomonas fluorescens 92rkG5: spatio-temporal dynamics, localization, organization, viability, and culturability. Microbial Ecology, August 2005, vol. 50, no. 2, p. 289-297.

GAMALERO, Elisa; BERTA, Guido; MASSA, Nadia; GLICK, Bernard R. and LINGUA, Guido. Synergistic interactions between the ACC deaminase-producing bacterium Pseudomonas putida UW4 and the AM fungus Gigaspora rosea positively affect cucumber plant growth. FEMS Microbiology Ecology, April 2008, vol. 64, no. 3, p. 459-467.

GUTIÉRREZ-MICELI, Federico A.; SANTIAGOBORRAZ, Jorge; MONTES-MOLINA, Joaquín A.; NAFATE, Camerino C.; ABUD-ARCHILA, Miguel; OLIVA-LLAVEN, María A.; RINCÓN-ROSALES, Reiner and DENDOOVEN, Luc. Vermicompost as a soil supplement to improve growth, yield and fruit quality of tomato (Lycopersicum esculentum). Bioresource Technology, November 2007, vol. 98, no. 5, p. 2781-2786.

GUTIÉRREZ-MICELI, F.A.; MOGUEL-ZAMUDIO, B.; ABUD-ARCHILA, M.; GUTIÉRREZ-OLIVA, V.F. and DENDOOVEN, L. Sheep manure vermicompost supplemented with a native diazotrophic bacteria and mycorrhizas for maize cultivation. Bioresource Technology, October 2008, vol. 99, no. 15, p. 7020-7026.

HASNA, M.K.; MÅRTENSSON, A.; PERSSON, P. and RÄMERT, B. Use of composts to manage corky root disease in organic tomato production. Annals of Applied Biology, August 2007, vol. 151, no. 3, p. 381-390.

HUANG, Xianqing; LU, Zhaoxin; BIE, Xiaomei; LU, FengXia; ZHAO, Haizhen and YANG, Shujing. Optimization of inactivation of endospores of Bacillus cereus by antimicrobial lipopeptides from Bacillus subtilis fmbj strain using a response surface method. Applied Microbiology and Biotechnology, February 2007, vol. 74, no. 2, p. 454-461.

LI, Y.S.; ROBIN, P.; CLUZEAU, D.; BOUCHÉ, M.; QIU, J.P.; LAPLANCHE, A.; HASSOUNA, M.; MORAND, P.; DAPPELO, C. and CALLAREC, J. Vermifiltration as a stage in reuse of swine wastewater: Monitoring methodology on an experimental farm. Ecological Engineering, April 2008, vol. 32, no. 4, p. 301-309.

LIN, Shan-shan; DOU, Wen-fang; XU, Hong-yu; LI, Huazhong; XU, Zheng-Hong and MA, Yan-he. Optimization of medium composition for the production of alkaline $\beta$ mannanase by alkaliphilic Bacillus sp. N16-5 using response surface methodology. Applied Microbiology and Biotechnology, July 2007, vol. 75, no. 5, p. 1015-1022.

LIU, Gao-Qiang and WANG, Xiao-Ling. Optimization of critical medium components using response surface methodology for biomass and extracellular polysaccharide production by Agaricus blazei. Applied Microbiology and Biotechnology, February 2007, vol. 74, no. 1, p. 78-83. 
MENA-VIOLANTE, Hortencia G.; OCAMPO-JIMÉNEZ, Omar; DENDOOVEN, Luc; MARTÍNEZ-SOTO, Gerardo; GONZÁLEZ-CASTAÑEDA, Jacquelina; DAVIES, Fred T. and OLALDE-PORTUGAL, Victor. Arbuscular mycorrhizal fungi enhance fruit growth and quality of chile ancho (Capsicum annuum L. cv San Luis) plants exposed to drought. Mycorrhiza, June 2006, vol. 16, no. 4, p. 261-267.

MIZUMOTO, Shinji and SHODA, Makoto. Medium optimization of antifungal lipopeptide, iturin A, production by Bacillus subtilis in solid-state fermentation by response surface methodology. Applied Microbiology and Biotechnology, August 2007, vol. 76, no. 1, p. 101-108.

POULTON, Jennifer L.; BRYLA, David; KOIDE, Roger T. and STEPHENSON, Andrew G. Mycorrhizal infection and high soil phosphorus improve vegetative growth and the female and male functions in tomato. New Phytologist, April 2002, vol. 154, no. 1, p. 255-264.

SÁNCHEZ-MONEDERO, M.A.; ROIG, A.; MARTÍNEZPARDO, C. and CEGARRA-PAREDES, J.C. A microanalysis method for determining total organic carbon in extracts of humic substances. Relationships between total organic carbon and oxidable carbon. Bioresource Technology, September 1996, vol. 57, no. 3, p. 291-295.

SAS INSTITUTE. Statistic Guide for Personal Computers. Version 6.04. SAS Institute; Cary, North Carolina, USA. 1989.

TU, Cong; RISTAINO, Jean B. and HU, Shuijin. Soil microbial biomass and activity in organic tomato farming systems: Effects of organic inputs and straw mulching. Soil Biology and Biochemistry, February 2006, vol. 38, no. 2, p. 247-255.

US Environmental Protection Agency (USEPA). Environmental regulations and technology: Control of pathogens and vector attraction in sewage sludge (including domestic septage). Under 40 CFR Part 503. Appendix F, G and I. EPA/625/R-92-013. US Environmental Protection Agency Office of Research and Development; Cincinnati, Ohio. USA. 1999.

WARBURTON, K. and PILLAI-MCGARRY, U. Executive Summary of InFoRM 2000. In: WARBURTON, $\mathrm{K}$; PILLAI-MCGARRY, U. and RAMAGE, D. eds. Integrated biosystems for sustainable development. Proceedings of the InFoRM 2000. National Workshop on Integrated Food Production and Resource Management. Brisbane, Australia, 2002, p. ix-xvi.

XIAO, Z.J.; LIU, P.H.; QIN, J.Y. and XU, P. Statistical optimization of medium components for enhanced acetoin production from molasses and soybean meal hydrolysate. Applied Microbiology and Biotechnology, February 2007, vol. 74, no. 1, p. 61-68.
ZALLER, Johan G. Foliar spraying of vermicompost extracts: Effects on fruit quality and indications of lateblight suppression of field-grown tomatoes. Biological Agriculture and Horticulture, 2006, vol. 24, no. 2, p. 165180. 